\title{
New Model Policy Implementation Gerbang Emas Bersinar to Increase the Human Development Index in Tabalong Regency
}

\author{
Anang Syakhfiani ${ }^{1}$, Sampara Lukman ${ }^{2}$, Khasan Effendy ${ }^{3}$, Marja Sinurat ${ }^{4}$ \\ 1,2,3,4 Institut Pemerintahan Dalam Negeri (IPDN), Indonesia \\ Email: anang.syafkani@gmail.com
}

\begin{abstract}
Tabalong Regency Human Development Index shows positive growth from year to year from 68, 08 in 2013 to 70.76 in 2017. The Implementation of the development movement policy towards prosperous communities or "Gerbang Emas Sejahtera" has been proven successful in increasing the HDI of Tabalong Regency. However, this policy is still felt to be less than optimal in terms of the welfare of the community because here the nature of the policy is still top-down where the government's role is still very dominant in terms of being a facilitator and policy initiator. Policies are needed that can provide a productive reciprocal relationship between government and society. This research tries to introduce a new model of policy implementation, namely mixed mode as a solution to the problem.
\end{abstract}

Keywords: Human Development Index, Policy Implementation, Mixed.

\section{A. INTRODUCTION}

Tabalong Regency is an area located in South Kalimantan Province with an administrative area based on Law Number 8 of 1965 concerning the Establishment of Tanah Laut Regency, Tapin Regency and Tabalong Regency (State Gazette of the Republic of Indonesia Year 1965 Number 51, Additional State Gazette of the Republic of Indonesia Number 2756) is $\pm 3,946 \mathrm{Km}^{2}$ or $\pm 394,600 \mathrm{Ha}$. However, after the boundaries and agreements were made between the Tabalong Regency Government and the South Barito Regency Government, the area of Tabalong Regency became $\pm 3,646.52 \mathrm{Km}^{2}$ or \pm $364,652 \mathrm{Ha}$, consisting of 12 sub-Regency, 121 villages and ten villages.

Based on data from the Central Statistics Agency of Tabalong Regency, the population of Tabalong Regency in 2017 was 247,106 people, with a male composition of 125,605 people and women of 121,501 people. The highest population is in Murung Pudak Sub Regency with 51,149 people, followed by Tanjung Sub Regency with 36,753 inhabitants, and the least is Muara Must Regency with 6,607 inhabitants.

Concerning the Human Development Index (HDI), the achievement of the Tabalong HDI shows positive growth from year to year. Tabalong HDI in 2013 amounted to 68,08 increased steadily and reached 70.76 in 2017. The achievement of Tabalong HDI number was 70.76 according to the concept of human development 
developed by the United Nations (UN) included in the category of high human development performance, which is in the range of $70 \leq \mathrm{HDI}<80$.

The growth trend of HDI value of South Kalimantan Province and Tabalong Regency is almost the same, which is increasing as shown by the data from 2013 to 2017. When compared to South Kalimantan Province, the HDI of Tabalong Regency is higher than the HDI of South Kalimantan Province in 2017, which amounted to 69.65. This shows that human development in Tabalong Regency is above the Province of South Kalimantan. One of the causes of the increase in the growth of the Human Growth Index in Tabalong Regency is due to the Policy of the development movement towards prosperous communities or known as "Gerbang Emas Bersinar" which is an idea as a movement that leads to actions towards improving community welfare in Tabalong Regency. Program is motivated by the theory of "Resource Curse" in which the proposition of the opinion, stating that the areas that are rich in natural resources tend to be the rate of economic growth, especially the Human Development Index (HDI) is low, due to drift with the conditions of the mining sector and even complacent with resources so that it defeats the fundamental divisions of an area on welfare.

\section{B. LITERATURE REVIEW}

\section{Human Development Index}

The debate about indicators of socio-economic development has long been happening. Per capita income as an indicator of development has been sued by economic and non-economic circles who see the inaccuracy of these indicators, which then led to several new indicators. New indicators generally focus on human development. Morris (1979) built the Physical Quality of Life Index (PQLI), while the United Nations Development Program (UNDP) built the Human Development Index (HDI) or Human Development Index (HDI) which is now widely used by countries in the world with a foundation created by Haq (1996).

UNDP first published the concept of HDI through the 1996 Human Development Report, which then continues every year. In this publication, human development is defined as "a process of enlarging people's choices" or processes that improve aspects of people's lives. The most important aspect of life is seen from the age of a long and healthy life, an adequate level of education, and standard of living. Specifically, UNDP defines four main elements in human development, namely productivity (equity), equity (capital), sustainability, and empowerment.

The Human Development Index (HDI) is a single composite indicator that although it cannot measure all dimensions of human development, it measures three fundamental aspects of social development that are considered capable of reflecting the necessary capabilities of the population. The three basic abilities are long and healthy, knowledgeable and skilled, and access to the resources needed to achieve a decent 
standard of living. UNDP defines human development as a process to expand choices for the population in terms of income, health, education, physical environment, and so on. Four main things that need to be considered in human development are productivity, equity, sustainability, empowerment (UNDP, 1995:12).

The number of goods and services in a country's economy can be interpreted as the value of the Gross Domestic Product (GDP). GDP is closely related to HDI. It may even be said that HDI is an improved welfare measure, while GDP is an old welfare measure. However, the two gauges do not always have to run linearly, because an increase in GDP without an increase in income distribution and allocation of activities that increase people's welfare also will not increase the HDI.

The tax collected by the government is government revenue to finance various expenses. These expenditures will be financing activities that can improve the welfare of the community so that the increase in taxes received by the government has the potential to increase the HDI. However, it must be noted that the tax collected by the government will reduce the disposable income of the community so that it has the potential to reduce the welfare of the community, and thus will reduce the HDI. This empirical research intends to reveal the direction of the relationship.

Brata (2005), examines how the influence of local government spending, especially in education and health, private investment (PI) and Gini index (GI) proxy income distribution to the human development index (HDI) in the regional context (between provinces) in Indonesia. Variable of government expenditure in education and health has a positive influence on the development of astronomer. The higher the expenditure allocation for education and health, the better the HDI will be achieved. The variable of private investment harms HDI. This is possible because the characteristics of private investment are not intended to improve the quality of human development. The GI variable has a positive effect on HDI, meaning that the more equitable the distribution of income, the better human development. The GI lag variable shows a significant adverse impact, in the long run, it will be increasingly difficult to improve the quality of HR through income distribution

Ginting (2008), analyzes the effect of household consumption on food and nonfood, government spending on education, the ratio of the poor population and the economic crisis on human development in Indonesia. The results showed a significant influence between household consumption for food and non-food, government spending on education, the ratio of the sparse population and the economic crisis to human development in Indonesia. The financial crisis dummy variable shows a negative influence.

\section{Policy Implementation Theory}

Van Meter and Van Horn in his book The Policy Implementation Process defines Implementation as "those actions by public or private individuals (or groups) that the 
area is directed at the achievement of objections outlined in prior policy decisions, which means actions taken both by and government or private individuals/officials or groups directed at achieving the objectives outlined in the policy decision.

The Implementation of the Van Meter and Van Horn Policy quoted from Nugroho (2011, p. 625) that determines the success of a policy can be seen from the planning of $20 \%$ (twenty per cent) and Implementation by $60 \%$ (sixty per cent), the rest is how to control the Implementation. The Van Meter and Van Horn policy implementation model can be described as follows:

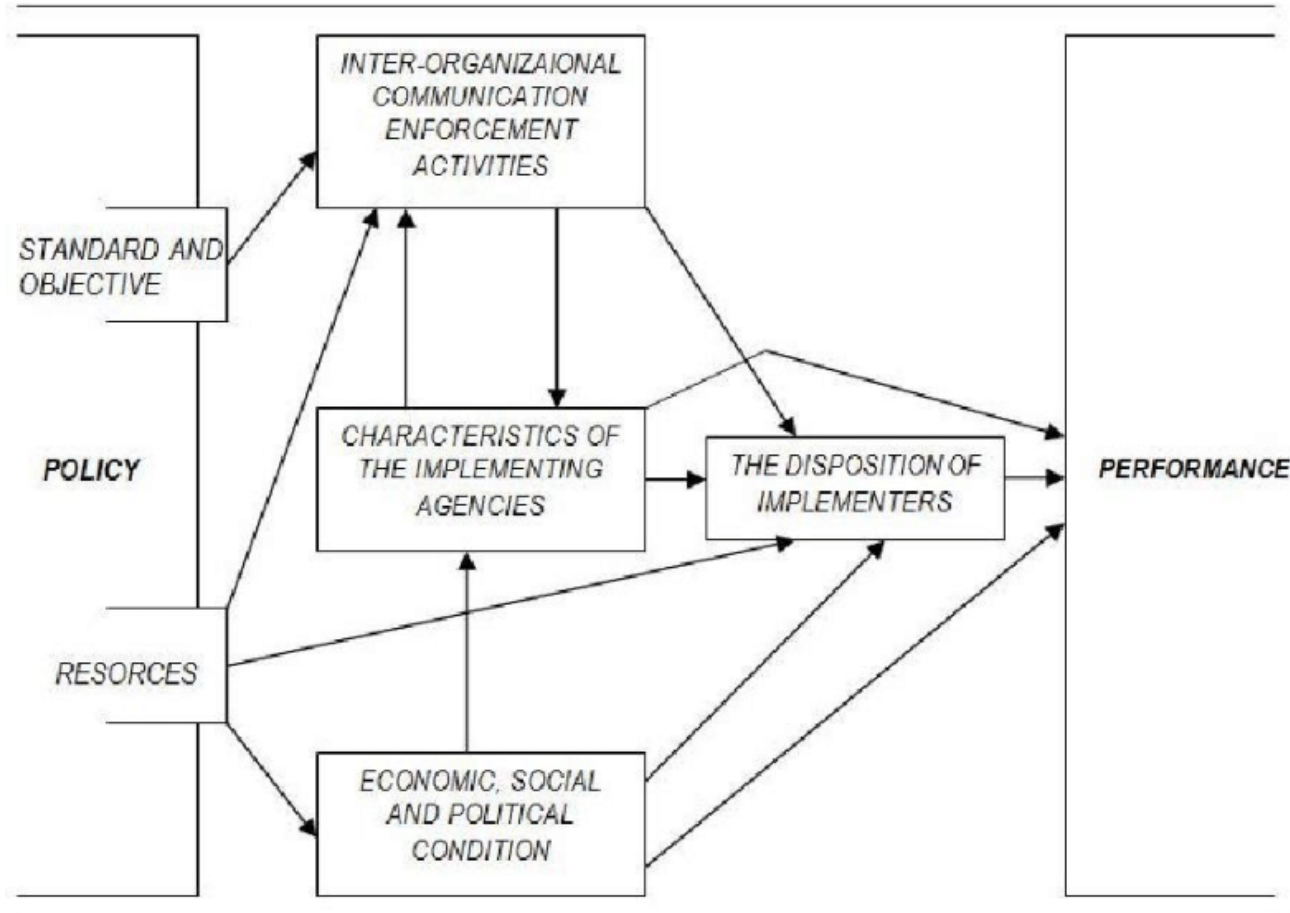

Figure 1 The Van Meter and Van Horn Policy Implementation Model (1975)

So some variables included as variables that influence public policy are the following variables: first, implementation activities and communication between organizations, second, the characteristics of implementing agents/implementers, third, economic, social and cultural conditions. Fourth, the tendency (disposition) of the implementer/implementation

Because in policies there are very complex problems, according to William Dunn (2003: 32) that "Policy Implementation" which is an activity to carry out policies/policy actions, usually contains the Implementation of various programs and therein often arises very complex problems and requires joint action. In the methodology of policy analysis combining five general procedures commonly used in solving human problems: definition, prediction, prescription, description and evaluation. In policy analysis, these procedures obtain unique names. 
The procedure of public policy analysis, according to William Dunn (1994:21), combines five general and commonly used methods in problem-solving are as follows:

a. Problem formulation produces information about the conditions that create policy problems;

b. Forecasting provides information about conditions that create policy problems;

c. Recommendations provide information about the relative value or usefulness of the future consequences of solving a problem.

d. Monitoring produces information about the present and past consequences of applied policy alternatives.

e. The evaluation provides information about the value or usefulness of the consequences of solving or resolving problems.

Another opinion is that according to George Edwards III (1980) that the problem in public administration is the lack of attention to Implementation, without the skills of implementing public policy, then the Implementation of a policy will not succeed, in public policy, there are two questions namely what preconditions are needed so that a The policy can be successful. The second is the AOPA obstacle which fails in Implementation. There are four factors so that policy implementation can achieve success, namely communication, sources, trends or dispositions and structure of Implementation.

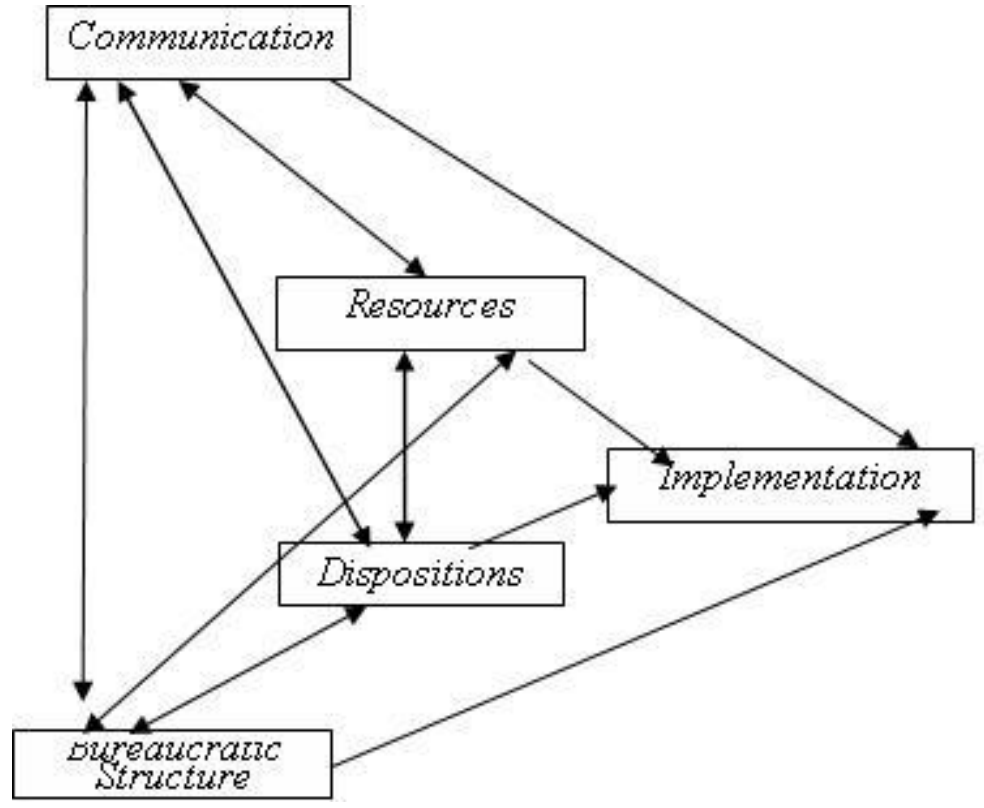

Figure 2 George Edward III Policy Implementation Model (1980)

Policy Implementation Model according to Mazmanian and Sebatier (1983) three variables affect a policy implementation, namely, First, tractability of the problem or characteristics of the problem, second, ability of statute to structure Implementation or aspects of policies/laws, Third, non-statutory Variables affecting implementation or environment variables. According to Wibawa (1994:25), the thoughts of Mazmanian 
and Sabatier were impressed that Implementation would be effective if the implementers obeyed the existing regulations.

Policy Implementation Framework (PIF)

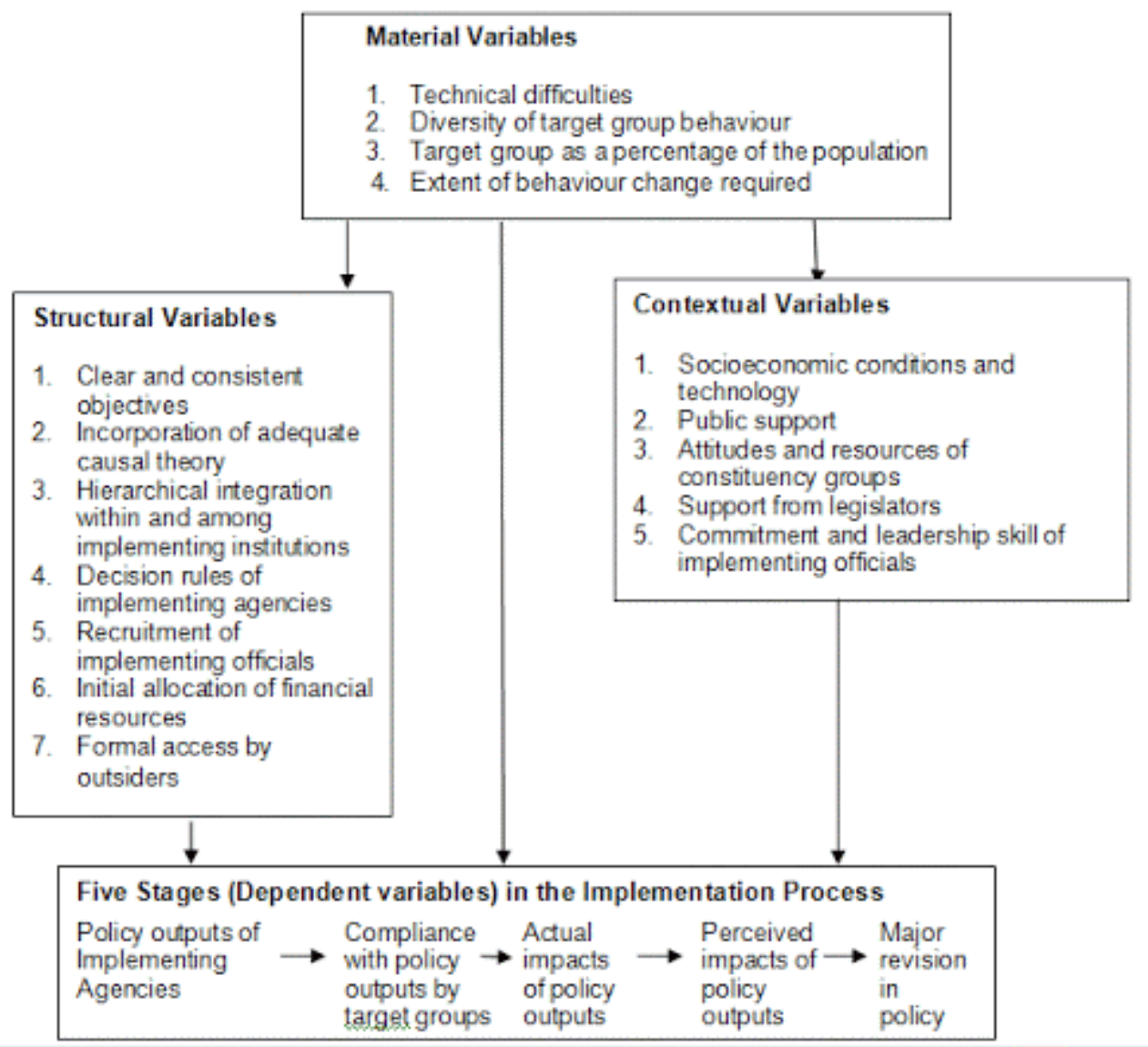

Figure 3 Sabattier \& Mazmanian Policy Implementation Model (1983)

The model of policy implementation according to Merille S Grindle (1980) quoted from Wibawa (1994:22-25) states that policy implementation is determined by the contents of the policy and its implementation context, the basic idea is that after the policy is transformed then the policy is carried out, its success is determined by the degree of its implementability the program, the contents of the policy include the following matters: First, the interests affected by the policy, second, the type or type of benefits to be generated, third, the degree of change desired, fourth, the position of the policymaker, fifth, who is the program implementer and sixth, the resources involved. 


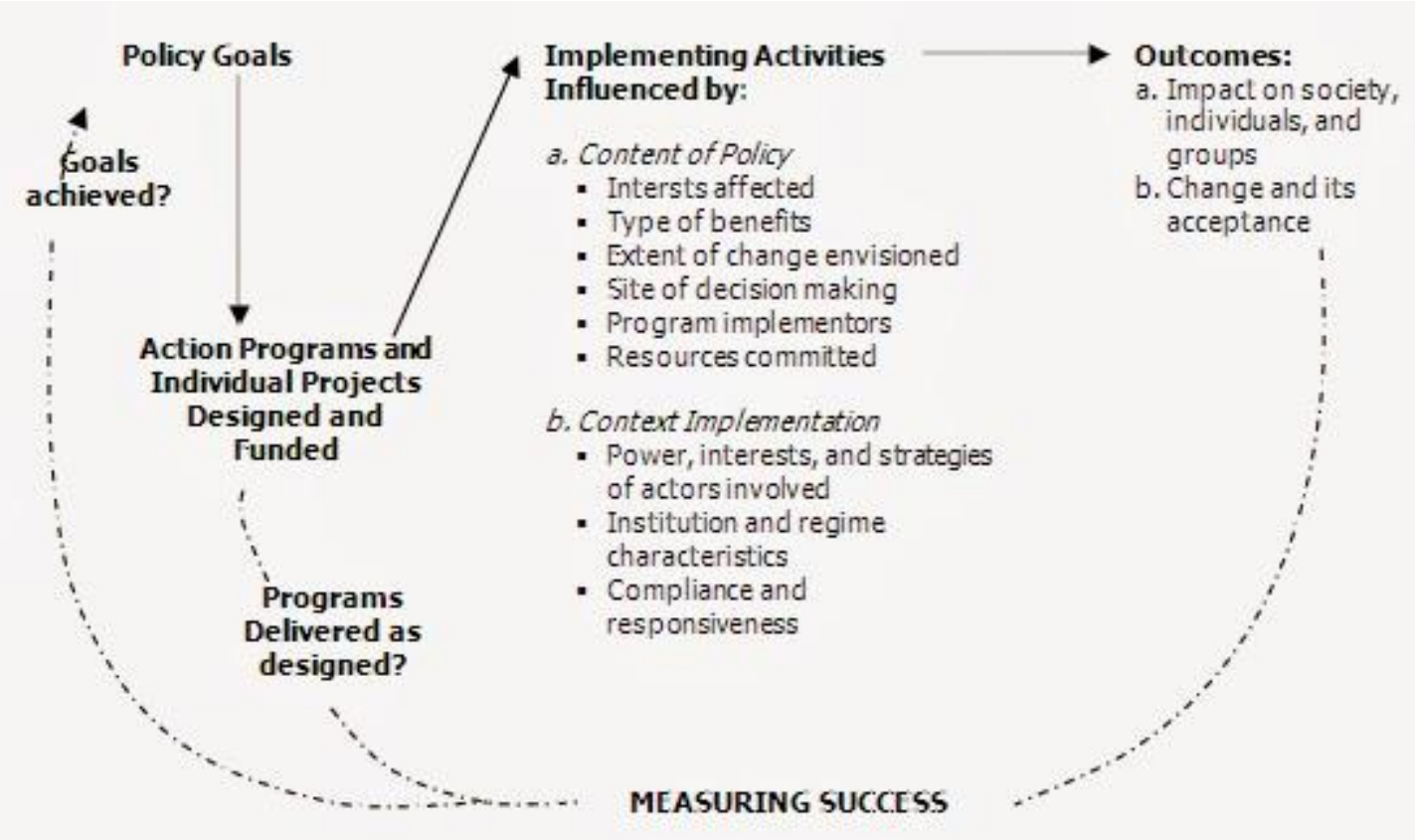

Figure 4 The Merilee S. Grindel (1980) Policy Implementation Model

\section{METHOD}

The approach used in this research is qualitative. Qualitative research requires guidance on the preparation of substantive theories based on data. The use of qualitative approaches is also adapted to the characteristics that exist that researchers are directly involved in the study site through participant observation. To achieve these objectives in this study, the author uses a qualitative approach (qualitative research) with a phenomenological approach. A study to produce accurate and maximum results, it is essential to have a research design that is appropriate to the situation and conditions as well as following the object to be studied so that the existing research design must be adapted to the object to be reviewed.

\section{RESULTS AND DISCUSSION}

In the context of the model of the Implementation of "Gerbang Emas Bersinar" policy in Tabalong Regency, the initiative is still dominantly owned by the Regional Government. This means that "Gerbang Emas Bersinar"s is a top-down policy with the hope that it can be a stimulus for increasing HDI in Tabalong Regency. The policy also focuses more on improving the economic sector as the primary target.

Based on this, the economic sector program in enhancing HDI can be seen as the backbone of "Gerbang Emas Bersinar" policy. In contrast, the education and health sector programs are still considered to be supporting the economy. This understanding arises with the assumption that the success of the economic sector will have a direct impact on education and health. 
"Gerbang Emas Bersinar" Policy can be seen as a form of initiation from the Regional Government of Tabalong Regency in the context of accelerating the increase in HDI. But in its Implementation, the policy requires the role of the private sector and the community towards the success of the program. In the private sector, the most visible role is funding CSR as a form of individual responsibility towards the community and its environment. Whereas in the community sector, the existence of compliance and awareness of the importance of the policy makes it easy to achieve goals.

Although in its Implementation, the "Gerbang Emas Bersinar" policy still requires various optimizations in various sectors, especially how the community is involved in policy planning. Communities have an essential role in a policy, where they not only act as recipients of impact but also as initiators of policy. The community is given the freedom of space for policy formation so that it is compatible with their needs and interests or better known as bottom-up, where the community has a dominant portion in determining policy, unlike the top-down context which emphasizes more on the government as the main initiator. One of the forms of freedom and the dominant role is the Development Plan Conference as a form of facilitation from the government for the aspirations of the people.

Fulfilment of these aspirations means providing a change in the function of the policy itself, in which the community is formed as an initiator and the Local Government as a policy facilitator, or can be said as a bottom-up policy, which provides an opportunity for the public to express their views and opinions on the existence of the "Gerbang Emas Bersinar" policy. The contextualization needs to be supported by the government's attitude which is responsive to the dynamics of the community, including being able to accommodate various interests of the community and determining the scale of policy priorities that are in line with the objectives of increasing HDI. This means that the Regional Government continues to play a role in establishing policies that are felt to have a high level of urgency.

Based on the understanding of top-down and bottom-up models, they still have fundamental challenges; namely, there is one passive policy actor. The top-down model will give the government a dominant role as a policy initiator, in which the community passively accepts the policy. That means it requires quality resources so that they can articulate the interests of their people. Besides, the condition of the top-down model also requires high trust from the community to the government, so that every Government action is suitable according to the community. However, if the prerequisites are not met, the potential for abuse of power or abuse of power is quite high.

Whereas in the bottom-up model, which indicates the need for good quality society and can articulate its interests to the government. These communities can voice their aspirations to the government, through various methods both directly and indirectly, and then become material for the government to form policies that are 
suitable to the needs of its people. This shows that the smallest form of community quality is political awareness, where each of their interests can be interpreted to the government. In the bottom-up model, the government tends to be passive and act as a facilitator of various community interests. Also, this model tends to require the ability of the government to be able to accommodate the attention of the whole community, especially in determining the right decision in the complex and dynamic conditions of society.

These fundamental challenges can be minimized through collaboration between the government and the community towards policy formation. The government and the community play a role as facilitators and policy initiators. This means that there is a need for a common goal of the policy taken by the government, where the government and the public are equally aware of the benefits and risks obtained in implementing the policy. These conditions make it possible to not only create trust and good relationship patterns between the government and the community but also be able to generate maturity between the two in the administration of government. On the other hand, the existence of private relations with the government and the community is also considered necessary, especially in maintaining the presence of the private sector as the owner and manager of capital. The need for the private sector in the pattern of relations is an effort to ensure the existence and equity of their capital is not interrupted by supporting programs between the government and the community. While the government and the community also need the private sector as part of the market (market) and employment. This means that the three sectors have their respective roles and functions in the administration of government.

The relationship makes it possible to create a patterned mix of policy approaches (mixed) by providing each portion between the government, civil society and the private sector. This pattern also relies on communication through the involvement of the three essential elements of government in policy formation.

Although in its Implementation, the government retains control over the determination of policies that are tailored to the priority scale and the degree of urgency. Besides, the communication of policy determination also plays an essential role in aligning and understanding policy objectives as parameters of success.

Model newly offered to find a solution to the inhibiting factors Shining Golden Gate Policy implementation to improve the welfare of people in Tabalong. Through collaboration between the government and the community towards policy formation, it is a proposal of the sustainability of "Gerbang Emas Bersinar". The mixed pattern model is considered to be able to synergize between the government and the community acting as facilitators and policy initiators. However, the model must be carried out in common perception of the policy objectives taken by the government together to find out the benefits and risks obtained in implementing the policy. The model is considered capable of creating trust and good relationship patterns between the government and 
the community, as well as creating maturity between the two in the administration of government. The model that connects the private sector with the government and the community is also considered necessary, especially in maintaining the existence of the private sector as the owner and manager of capital.

\section{E. CONCLUSION}

The implementation policy of the "Gerbang Emas Bersinar" in the Tabalong Regency of South Kalimantan province is in principle carried out to improve the Human Development Index; this is because in the period up to 2013 the Human Development index in the Tabalong regency ranks 9 and 10 in the South Kalimantan province. It is indeed very ironic if one considers the Tabalong rich condition will be natural resources.

The Implementation of "Gerbang Emas Bersinar" Policy itself so far only follows the method proposed by Merille S Grindle (1980), where the initiative is still dominantly owned by the Regional Government. This means that the "Gerbang Emas Bersinar"s is a top-down policy with the hope that it can be a stimulus for increasing HDI in Tabalong Regency.

The new model introduced in the Implementation of the "Gerbang Emas Bersinar" policy, namely the Mixed pattern model, is expected to be able further to enhance the welfare of the community in Tabalong Regency. This model can be a solution to the inhibiting factors for the Implementation of "Gerbang Emas Bersinar" Policy because this model offers a synergy between the government and the community who act as facilitators and policy initiators. This model is considered capable of creating confidence and good relations between government and society.

\section{REFFERENCES}

1. Adisasmita, R. (2006). Pembangunan Perdesaan dan Perkotaan. Yogyakarta: Graha Ilmu.

2. Arikunto, S. (1998). Prosedur Penelitian: Suatu Pendekatan Praktek. Jakarta: Rineka Cipta.

3. Arsyad, L. (1999). Pengantar Perencanaan dan Pembangunan, Ekonomi Daerah. Yogyakarta: BPFE.

4. Creswell, J. W. (2016). Pendekatan Metode Kualitatif, Kuantatif, dan Campuran.Yogyakarta. Pustaka Pelajar.

5. Dinar, A. L. (2015). Implementasi Program Gerakan Pembangunan Desa Terpadu (Gerbang Sadu) Mandara di Desa Sibetan Kecamatan Bebandem Kabupaten Karangasem Bali (Studi Pada Kelompok Usaha Ekonomi Produktif). Publika, 3(5), 114.

6. Dye, T. R. (1978). Understanding Public Policy. New Jersey: Prentice Hall. 
7. Effendy, K. (2010). Sosiologi Pemerintahan. Bandung: Indraprahasta.

8. Government Regulation Number 43 of 2014 concerning Implementing Regulation of Law Number 6 of 2014 concerning Villages.

9. Hanif, N. (2011). Pertumbuhan dan Penyelenggaraan Pemerintahan Desa. Jakarta: Erlangga.

10. Harli, M. (2013). Implementasi Program Gerakan Pembangunan Rakyat (Gapura) Sa-Ijaan di Desa Sungai Kupang Jaya Kecamatan Kelumpang Selatan Kabupaten Kotabaru Kalimantan Selatan. Jurnal Ilmu Politik \& Pemerintahan Lokal, 2(2), 302-310.

11. Istianto, B. (2011). Manajemen Pemerintahan (Dalam Perspektif Pelayanan Publik), Jakarta: Mitra Wacana Media.

12. Jati, H., Astuti, I., \& Fernandez, D. (2015, November). Implementasi Inovasi Program Gerakan Membangun Ekonomi Masyarakat (Gerbang Emas) Dalam Meningkatkan Pendapatan Usaha Mikro Kecil di Kabupaten Flores Timur. In Seminar Nasional Riset Inovatif (Vol. 3).

13. Law Number 25 of 2004 concerning the National Development Planning System.

14. Law Number 11 of 2009 concerning Community Welfare Act Number 6 of 2014 concerning Villages.

15. Maryuni, S. (2016). Implementasi Program Nasional Pemberdayaan Masyarakat (PNPM) Mandiri Perkotaan di Kota Pontianak. PROYEKSI-Jurnal Ilmu Sosial dan Humaniora, 19(01).

16. Minister of Home Affairs Regulation No. 86 of 2017 concerning Procedures for Planning, Control and Evaluation of Regional Regulation Draft Regarding Regional Long-Term Development Plans and Regional Medium-Term Development Plans, As well as Procedures for Changing Regional Long-Term Development Plans and Regional Medium-Term Development Plans and Plans Local Government Work.

17. Minister of Home Affairs Regulation Number 114 of 2014 concerning Guidelines for Village Development.

18. Moleong, L. J. (2008). Metodologi Penelitian Kualitatif. Bandung: Remaja Rosdakarya.

19. Mudrajat, K. (2011). Perencanaan Daerah: Bagaimana Membangun Ekonomi Lokal, Kota dan Kawasan. Jakarta: Salemba Empat.

20. Ndraha, T. (2011). Kybernology (Ilmu Pemerintahan Baru). Jakarta: Rineka Cipta.

21. Pudjianto, W. S. (2019). Pendekatan Baru Perencanaan Pembangunan Daerah. Jakarta: Kompas Media Nusantara.

22. Sinurat, M., \& Panjaitan, H. M. (2017). Perencanaan dan Penganggaran Daerah. Bandung: Pustaka Rahmat.

23. Suharyadi, H., \& Insani, M. A. (2016). Manajemen Pemerintahan Dalam Program Unit Reaksi Cepat Tambal Jalan di Kota Bandung Tahun 2015. Jurnal Ilmu Pemerintahan, 2(2), 241-243.

24. Wasistiono, S. (2003). Kapita Selekta Manajemen Pemerintahan Daerah. Bandung: Fokusmedia. 